\title{
PRE-COLUMBian GEMS AND ORNAMENTAL MATERIALS FROM ANTIGUA, WEST INDIES
}

\author{
By A. Reg Murphy, David J. Hozjan, Christy N. de Mille, and Alfred A. Levinson
}

Two archeological sites that were discovered recently on the island of Antigua appear to have had flourishing lapidary industries. Excavation of these sites, which date to about 250-500 AD (Saladoid period), has revealed beads, pendants, and "zemis" made from a variety of materials, with shell being the most abundant. All of the unworked materials (e.g., shell, carnelian, and diorite) are of local origin. However, amethyst, nephrite, serpentine, and turquoise were found only as finished gems; these are not local and imply that trade or exchange existed between Antigua and other parts of the Caribbean and possibly the Americas during Saladoid time.

\section{ABOUT THE AUTHORS}

Dr. Murphy (museum@candw.ag) is an archeologist at the Museum of Antigua and Barbuda, St. John's, Antigua. Mr. Hozjan is a geologist with Overburden Drilling Management Ltd., Ottawa, Canada; and Ms. de Mille is a doctoral student in the Department of Archeology, University of Calgary, Alberta, Canada. Dr. Levinson (levinson@geo.ucalgary.ca) is professor emeritus in the Department of Geology and Geophysics, University of Calgary.

Please see acknowledgments at the end of the article.

Gems \& Gemology, Vol. 36, No. 3, pp. 234-245 (C) 2000 Gemological Institute of America

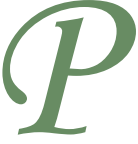

re-Columbian gems and ornamental materials (fashioned as beads, pendants, and "zemis" [distinctive pointed religious objects]) from the Caribbean Islands have been known since the 1870s (Watters, 1997a). Although such materials from various islands have been described in anthropological or archeological publications (e.g., Ball, 1941; Cody, 1991a; Watters and Scaglion, 1994), they have not been documented previously from the island of Antigua.

Two archeological sites discovered recently on Antigua-Elliot's and Royall's (Murphy, 1999)—clearly were jewelry manufacturing centers, as evidenced by the presence of gem and ornamental materials in all stages of manufacture, from the raw material to the finished product (e.g., Watters, 1997b). Previously, only a few other isolated prehistoric gem items composed of minerals or rocks (carnelian and diorite) were discovered on Antigua, although shell beads are fairly common (Murphy, 1999). In this article, we report the results of our research on the ancient jewelry industry of Antigua by cataloguing the lapidary objects and identifying the minerals and rocks from which they are fashioned (see, e.g., figure 1), as well as suggesting whether they are of local or nonlocal geographic origin. We then compare these results to those for three other lapidary-containing archeological sites in the eastern Caribbean Islands.

\section{DESCRIPTION OF THE SITES}

The site at Elliot's was discovered in early 1996 while the land was being prepared for agriculture. It covers an area of about $5,550 \mathrm{~m}^{2}$. The Royall's site, discovered in January 1998 during land clearing for a housing development, covers an area of about $39,000 \mathrm{~m}^{2}$; it is the largest of at least 120 known prehistoric archeological sites on Antigua 


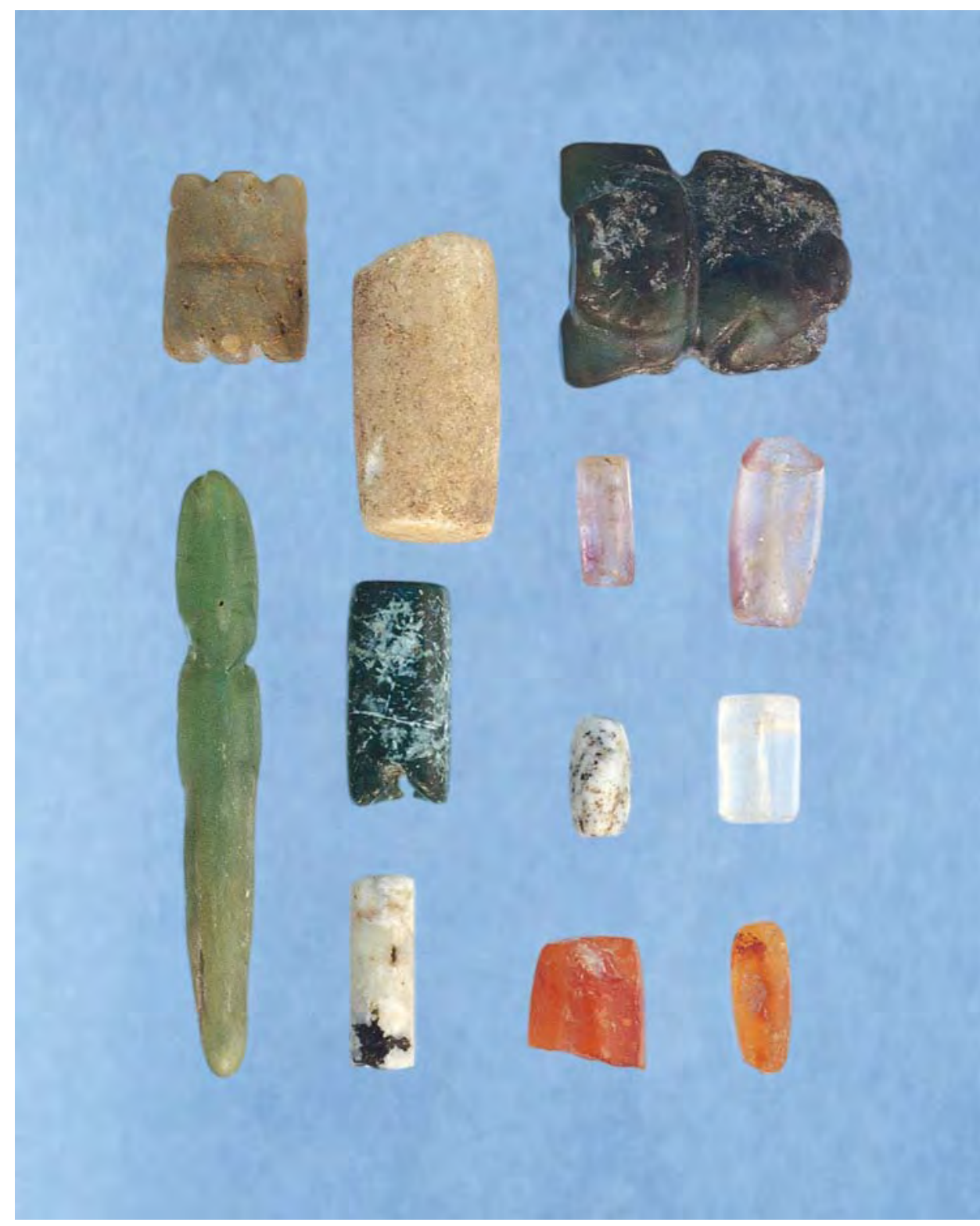

Figure 1. These beads and pendants are representative of the many different lapidary objects that were recovered from the Elliot's site on the Caribbean island of Antigua. From the top left: Column $1=$ tuff, nephrite; column 2 = barite, serpentine, diorite; column $3=$ nephrite (frog carving), amethyst, chalcedony; carnelian (fragment); column 4 = amethyst, quartz, carnelian. All of these objects are finished except for the barite and chalcedony, which lack drilled holes. Note, for scale, that the nephrite carving in column 1 is 6.5 $\mathrm{cm}$ long and $0.7 \mathrm{~cm}$ wide.

(Nicholson, 1993). The sites are located approximately $12 \mathrm{~km}$ (7 miles) apart (figure 2), amid grassland and scrub vegetation. Their names are derived from nearby historical sugar plantations (on some maps or in other publications, these localities are spelled "Elliots" and "Royal's" or "Royals").

Within two weeks of the discovery of each site, members of the Museum of Antigua and Barbuda began surface reconnaissance. It was immediately evident that the sites contained a diverse selection of the material culture of the early inhabitants, including lapidary and ceramic items, as well as stone artifacts such as axes. Surface sampling conducted in July 1998 by the University of Calgary Archeology Field School Antigua confirmed the temporal and cultural affiliation of these ancient settlements.

\section{BACKGROUND}

Archeology. The human history of Antigua is intimately associated with that of the other islands in the Lesser and Greater Antilles (again, see figure 2 ), and derives from the migration of ancient Amerindians from mainland regions (Wilson, 1997a, b). The earliest substantiated settlement in Antigua is dated at about $1775 \mathrm{BC}$ (Nicholson, 1993). In approximately 450 BC, Saladoids began to settle in the Antigua region (Rouse, 1976; Murphy, 1999). Saladoid is a generic name given to an Arawak-speaking, pre-Columbian, ceramic- and agriculture-oriented people from the lower Orinoco River valley; the type archeological site is at Saladero, Venezuela (Rouse, 1992; Allaire, 1997). Over time, the Saladoids traveled from Trinidad 


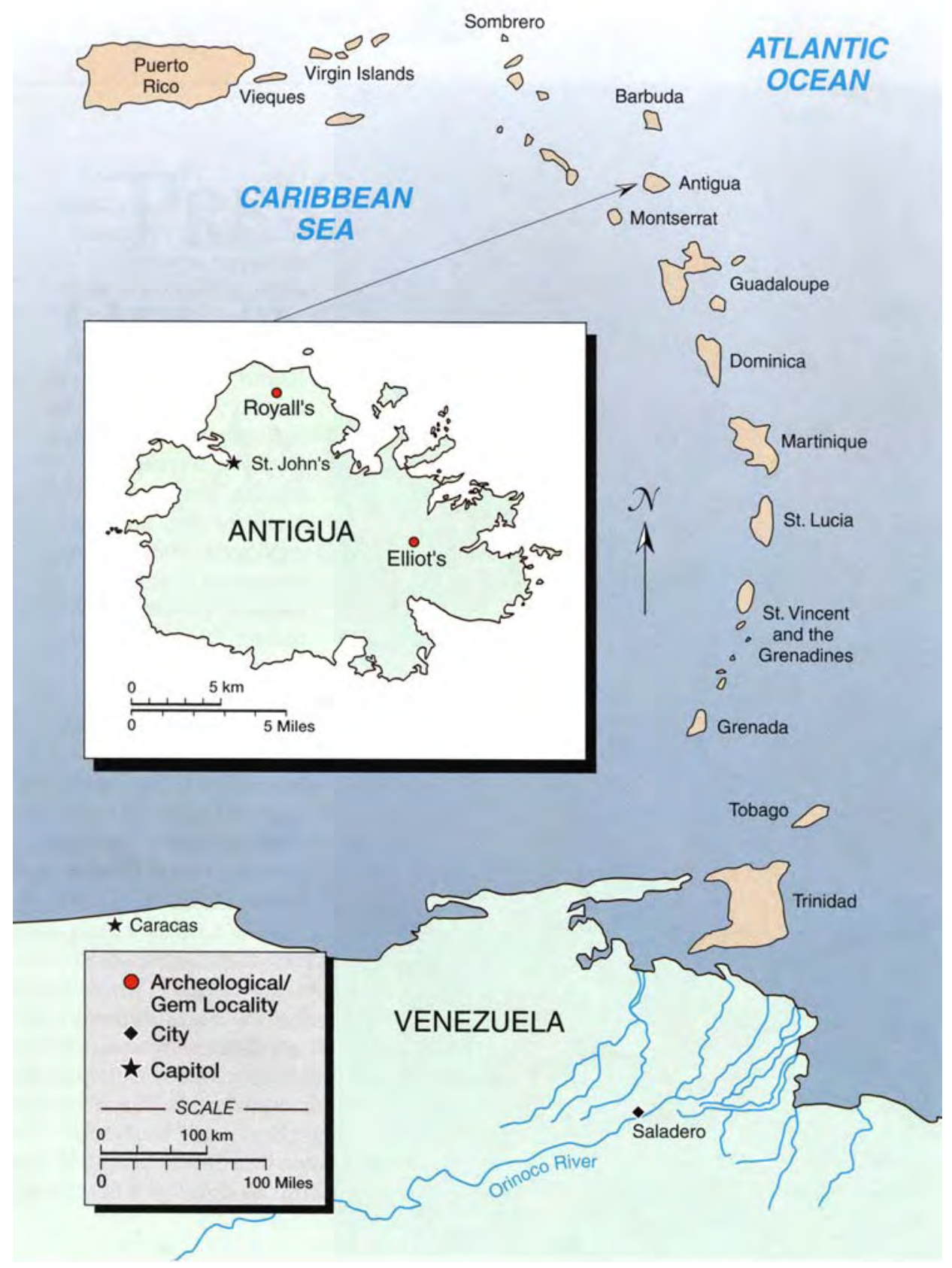

Figure 2. The Lesser Antilles is a chain of predominantly volcanic islands that stretches about $700 \mathrm{~km}$ (435 miles) along the eastern part of the Caribbean Sea, from the Virgin Islands and Sombrero in the north to Trinidad in the south. The Greater Antilles is another group of mainly larger islands to the north and west that includes Cuba, Jamaica, Hispaniola, and Puerto Rico. The West Indies includes the Lesser Antilles, the Greater Antilles, and the Bahamas. The Elliot's and Royall's archeological sites are located in eastern and northern Antigua, respectively, only about $12 \mathrm{~km}$ from each other.

northward to the Virgin Islands and Puerto Rico.

The lapidary items described here are associated with the Saladoid culture, specifically during the period 250-500 AD. This is based on carbon-14 age dates of 435 and 440 AD on charcoal at the Royall's site, and on diagnostic pottery at both the Royall's and Elliot's sites (figure 3). These sites are representative of the peak of Saladoid culture and artistry (Murphy, 1999).

Over time, certainly from 800 AD onward, the Saladoid culture evolved into various regional island cultures throughout the Antilles. The Historic Age of the Leeward Islands (the northern half of the Lesser Antilles, which includes Antigua) began in 1493 with their discovery by the Spanish. It appears, however, that the complex artistry and lapidary skills of the Saladoid culture had been lost by that time (Nicholson, 1993; Murphy, 1999). It is also evident that there was no trade in nonindigenous gem materials, because no such materials have been found in post-Saladoid archeological sites (Rouse, 1992; Crock and Bartone, 1998). The earliest European settlement of Antigua was British colonization in 1632 (Nicholson, 1991).

Geology. A brief review of the geology of Antigua is useful for inferring the local or nonlocal origin of the gems and ornamental materials recovered.

Of the several studies that have been made on the geology of the Lesser Antilles in general, and of Antigua in particular, those by Martin-Kaye (1969), Multer et al. (1986), and Weiss (1994) are particularly 
applicable to this report. These islands form an arcuate chain that separates the Caribbean Sea from the Atlantic Ocean (again, see figure 2). The location of the islands, and the great amount of volcanic activity characteristic of this part of the Caribbean, is related to plate tectonics, specifically to the subduction of the Atlantic Plate under the Caribbean Plate.

Essentially, Antigua is made up of volcanic rocks on which limestones were deposited; all the rocks are Oligocene in age (ca. 36-23 million years old). The island is divided into three geologic regions with distinctive physiographic characteristics (figure 4). As summarized from Weiss (1994):

- The Basal Volcanic Suite occupies the southwestern $40 \%$ of Antigua. It consists mainly of basalt and andesite flows, and pyroclastic rocks (e.g., tuff). The Suite also contains some minor intrusive plugs (e.g., quartz diorite), dikes, and sills, as well as some sedimentary rocks (e.g., limestones) intercalated with the volcanics. This part of the island is characterized by rugged topography.

- The Central Plain Group occupies the central $20 \%$ of the island. It consists predominantly of sedimentary rocks (e.g., limestone, chert), with minor amounts of volcanic rocks (e.g., tuff).

Figure 3. Anthropomorphic (human-like) effigies such as these, which are common on ceramic vessels from the Saladoid period, helped establish the approximate time period when these lapidary sites were active. These figurines were found at the Royall's site, but identical objects have been recovered from Elliot's and many other 250-500 AD Saladoid sites in the Lesser Antilles and Venezuela. The larger effigy is about $7.8 \mathrm{~cm}$ in its long direction.

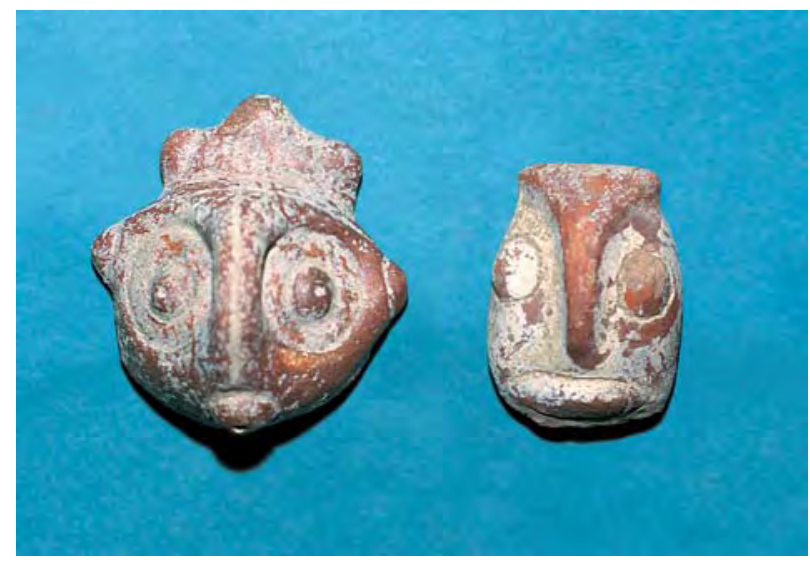

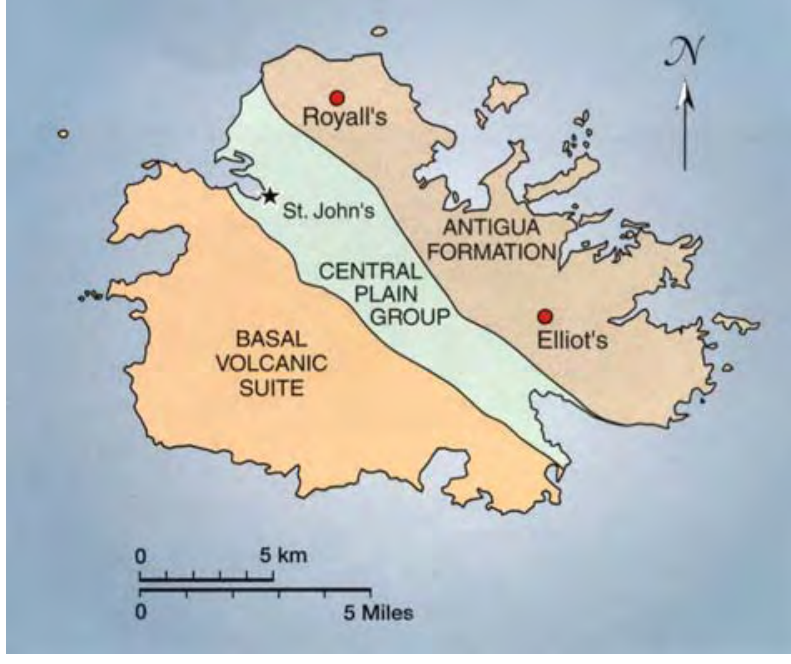

Figure 4. This simplified geologic map of Antigua illustrates the three main rock units (after Weiss, 1994). The Elliot's and Royall's ancient lapidary sites are on the Antigua Formation, which consists mostly of carbonate rocks (limestones and ancient coral reefs).

Topographically, the Group occupies an area of low relief.

- The Antigua Formation, the youngest of the three regions, occupies the northeastern $40 \%$ of Antigua, including the smaller offshore islands. It consists predominantly of limestones and ancient coral reefs. The area is moderately rugged, and the highly indented coast is characterized by bays fringed with mangroves and sand beaches. Many living coral reef communities thrive within and offshore the bays and islands. The Elliot's and Royall's lapidary industry sites are found within this geologic formation.

\section{MATERIALS AND METHODS}

Preliminary surface (figure 5) and subsurface sampling was conducted at each site to confirm its archeological nature. Subsequently, four pits (each 1 $\mathrm{m}^{2}$ ) at Royall's (see, e.g., figure 6) and one at Elliot's were excavated by brush and trowel, in $10 \mathrm{~cm}$ levels. All soil was passed through $2 \mathrm{~mm}$ mesh sieves to facilitate the recovery of minute beads and lithic by-product debris; material smaller than $2 \mathrm{~mm}$ was discarded. All cultural material recovered, including beads and raw materials that showed evidence of having been worked, was retained for analysis (see Murphy, 1999, for further details of the field procedures). By mid-1999, less than one percent of the area of each site had been studied.

A total of 642 specimens collected over two field seasons (during the summers of 1997 and 1998) were selected for this research: 149 from Elliot's (see, e.g., figure 1) and 493 from Royall's. They were 
TABLE 1. Saladoid gem and ornamental materials from Antigua identified in this study. ${ }^{a}$

\begin{tabular}{|c|c|c|c|c|c|c|c|c|c|c|}
\hline \multirow[b]{2}{*}{$\begin{array}{l}\text { Gem and orna- } \\
\text { mental materials }\end{array}$} & \multicolumn{5}{|c|}{ Elliot's site } & \multicolumn{5}{|c|}{ Royall's site } \\
\hline & $\begin{array}{c}\text { Raw } \\
\text { material }\end{array}$ & $\begin{array}{l}\text { Beads } \\
\text { (blank) }\end{array}$ & $\begin{array}{l}\text { Beads } \\
\text { (finished) }\end{array}$ & $\begin{array}{l}\text { Pendants } \\
\text { (finished) }\end{array}$ & Zemis & $\begin{array}{c}\text { Raw } \\
\text { material }\end{array}$ & $\begin{array}{l}\text { Beads } \\
\text { (blank) }\end{array}$ & $\begin{array}{l}\text { Beads } \\
\text { (finished) }\end{array}$ & $\begin{array}{l}\text { Pendants } \\
\text { (finished) }\end{array}$ & Zemis \\
\hline \multicolumn{11}{|l|}{ Quartz family gems } \\
\hline Amethyst & & & 3 & & & & & & & \\
\hline Carnelian & 1 & & 2 & & & 45 & 7 & 4 & & \\
\hline Chalcedony & 7 & 3 & & & & 5 & 2 & 1 & & \\
\hline Chert & 1 & & & & & 1 & & 1 & & \\
\hline Jasper & & & & & & 3 & & & & \\
\hline Quartz & 6 & & 3 & & & 13 & 2 & 3 & & \\
\hline \multicolumn{11}{|c|}{ Other gem materials } \\
\hline Barite & 2 & 1 & 1 & & & 5 & 2 & 1 & & \\
\hline Calcite & 1 & 3 & 1 & & & 36 & 5 & 18 & & \\
\hline Malachite & & 1 & & & & & & & & \\
\hline Nephrite & & & & 2 & & & & & 1 & \\
\hline Serpentine & & & 1 & & & & & 3 & & \\
\hline $\begin{array}{l}\text { Shell (aragonite/ } \\
\text { calcite) }\end{array}$ & $-^{b}$ & 21 & 52 & & 9 & $-^{b}$ & 72 & 181 & 34 & 7 \\
\hline Turquoise & & & & & & & & 1 & & \\
\hline \multicolumn{11}{|l|}{ Rocks } \\
\hline Diorite & & & 6 & & 2 & & & 11 & 4 & \\
\hline Limestone & & 6 & 1 & 5 & & 8 & $6^{c}$ & 6 & 3 & \\
\hline Tuff & & & & 7 & 1 & 2 & & & & \\
\hline Total & 18 & 35 & 70 & $\overline{14}$ & 12 & $\overline{118}$ & 96 & $\overline{230}$ & 42 & 7 \\
\hline
\end{tabular}

${ }^{a}$ All gem materials and rocks are inferred to be from Antigua except amethyst, nephrite, serpentine, and turquoise.

${ }^{b}$ Raw shell material was not included because it is difficult to distinguish food-related shells from those intended for other purposes.

Includes three samples of travertine.

in thin section), and an R.I. of about 1.54 (as determined on the one specimen polished specifically for this study). We use the term chert for a microcrystalline siliceous rock of sedimentary origin, which may contain amorphous silica (opal) and the siliceous remains of organisms, in accordance with the definition of Jackson (1997).

\section{RESULTS}

Of the 642 specimens from both sites, we categorized 300 finished beads, 131 blank beads, 56 finished pendants (no pendant blanks were recovered), 19 zemis, and 136 raw materials (table 1). We identified 13 gem materials and three rock types. Nine of the gems were identified by X-ray diffraction analysis (augmented by visual discrimination and thinsection study in the case of the quartz family gems): aragonite (shell), barite, calcite (both shell and nonbiogenic types), carnelian, chalcedony, chert, malachite, nephrite, and serpentine (see, e.g., figure 1). The remaining four gem materials were determined by their physical properties (e.g., S.G.) and/or chemical components by SEM-EDS: amethyst, jasper, quartz (colorless or near-colorless, transparent or translucent), and turquoise. Our identifications of five finished specimens were confirmed by Raman analysis: nephrite (2 samples), serpentine (antigorite; 2 ), and turquoise (1). One finished specimen we identified as nephrite could not be confirmed by Raman analysis because of the poor surface polish. The three rock types were identified as diorite, limestone (including travertine), and tuff by petrographic (thin section) and binocular microscopy, as well as by visual observation.

Various green materials with specific gravities of 2.2-2.6 were common at both sites, and presented special problems in both identification and nomenclature. Figure 7 illustrates six such specimens, which were identified by a combination of $\mathrm{X}$-ray diffraction analysis and thin-section and microscopic studies as: chalcedony (3 samples), tuff (2), and chert (1).

Gem Materials. Quartz Family Minerals. The three amethyst beads are semi-transparent, pale purple, and grade into colorless quartz (again see figure 1). The carnelian samples are semi-transparent to translucent brownish red to orangy red (figures 1 


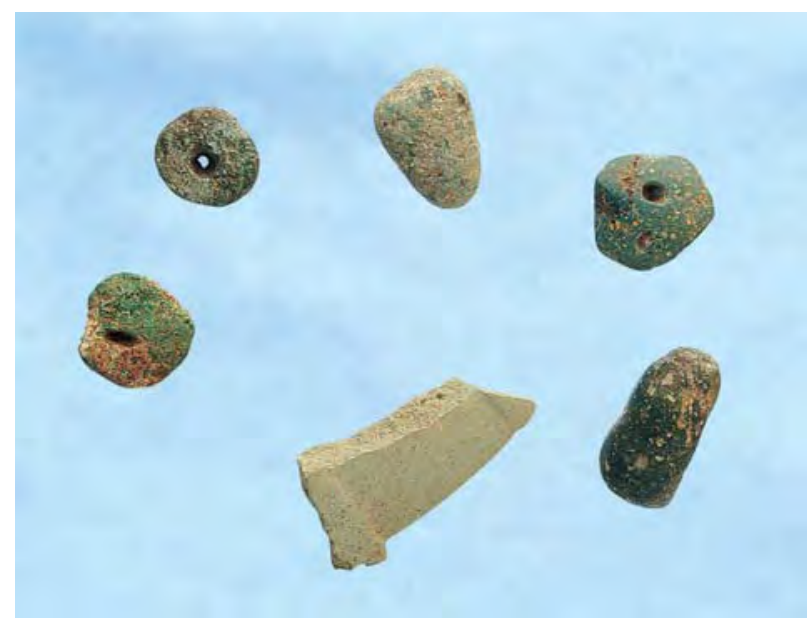

Figure 7. These green specimens, which are similar in both appearance and specific gravity (2.2-2.6), could not be identified conclusively without the use of $X$-ray diffraction analysis or other advanced techniques. They are (clockwise, from the large specimen on the bottom): tuff (about $3 \mathrm{~cm}$ long), malachite-rich tuff bead blank, chert bead, with all of the last three chalcedony.

Figure 8. Carnelian was one of the most common gem varieties observed at the two lapidary sites, as raw material, blanks, and finished beads. These are from the Royall's site; the smallest bead measures approximately $12 \mathrm{~mm}$ and the largest piece of rough, $4 \mathrm{~cm}$.

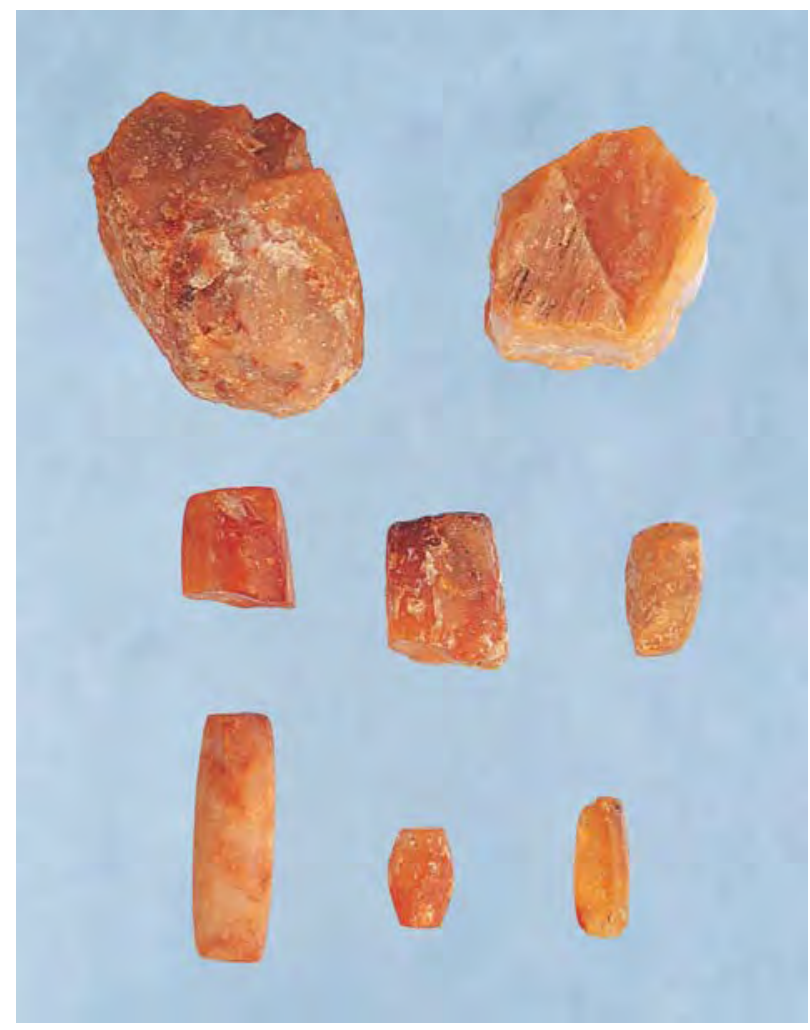

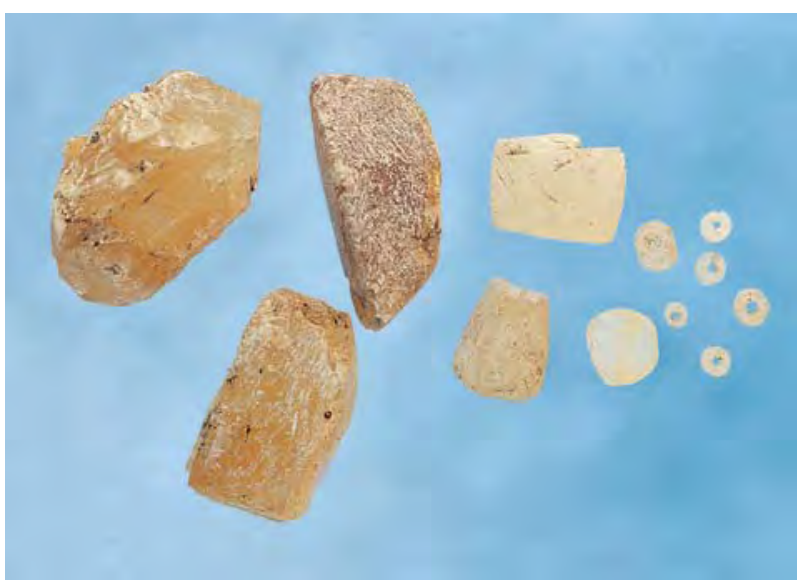

Figure 9. Shown here are a variety of semi-transparent to translucent objects from the Royall's site that have been fashioned from single crystals or masses of calcite (which is distinct from the opaque calcite derived from shells). They represent all stages in the production of small beads. The smallest bead shown here measures approximately $3 \mathrm{~mm}$; the largest piece of rough, $4 \mathrm{~cm}$.

and 8). The chalcedony objects (figures 1 and 7) are either white or green.

Two green chert specimens from the Royall's site (again, see figure 7) were found to consist of quartz, cristobalite, and mordenite; one also contained analcime. A green radiolarian chert was found at Elliot's. The three specimens of jasper raw material are opaque due to admixture with abundant iron oxides. Transparent colorless quartz beads and pieces of rough were found at both sites (figure 1).

Figure 10. This $9 \times 11 \mathrm{~mm}$ bead, from the Royall's site, is the only piece of turquoise identified from the samples studied. Photo by Maha Tannous.

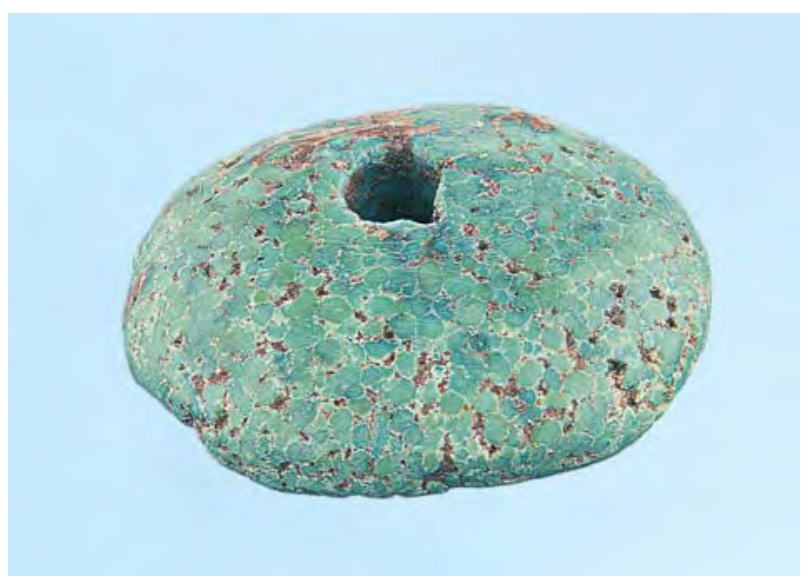




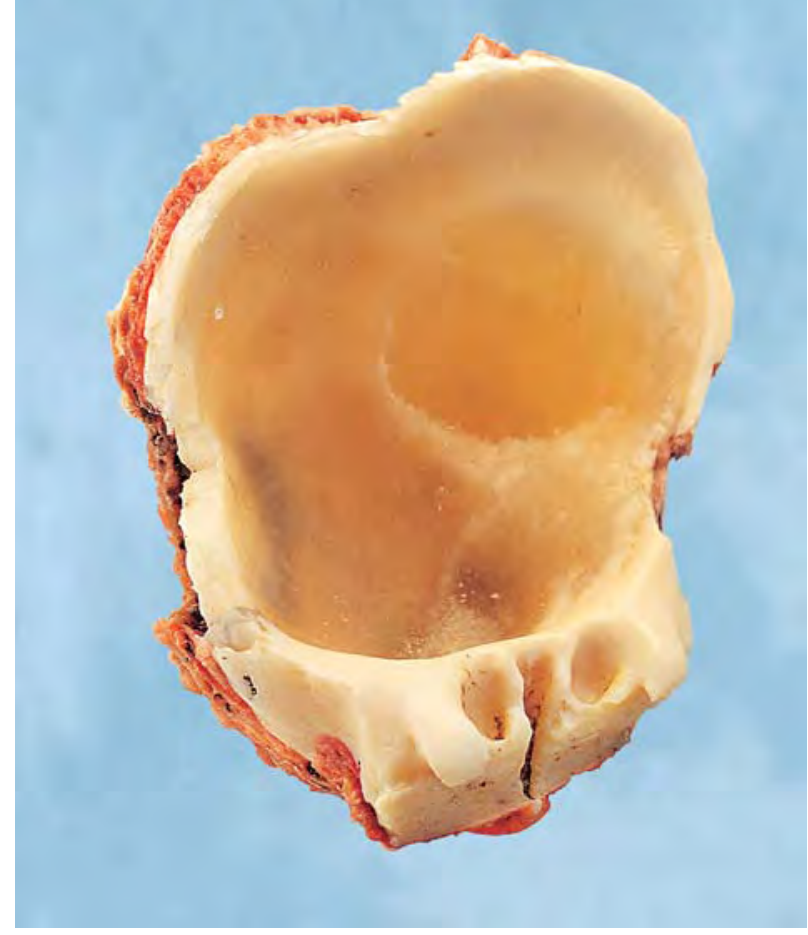

Figure 11. Note that there are two parts to this thorny oyster (Spondylus americanus) shell: The inner (white) part is composed of aragonite, while the outer (red) part has been converted to calcite. The specimen is about $9.6 \mathrm{~cm}$ long and $7.6 \mathrm{~cm}$ wide.

Other Gem Materials. Also as illustrated in figure 1 , a small number of white to yellowish white opaque pieces and finished beads of barite were found at each site. Calcite (white to tan) was particularly abundant at the Royall's site. The semi-transparent to translucent calcite fashioned from crystals (figure 9) is easily separated from the opaque calcite derived from shell, which typically has a reddish component (discussed below).

One specimen of malachite-rich tuff (figure 7) was found at the Elliot's site. The three finished pendants identified as nephrite (two are shown in figure 1) range from slightly yellowish green to very dark green. The serpentine beads (again, see figure 1) range from yellowish green to dark green. One small bluish green turquoise bead was found at the Royall's site (figure 10).

Shell was the most abundant locally available ornamental material; it represents $74 \%$ of all the worked (i.e., finished and blank) objects in this study. Thirteen species of shellfish have been identified at the Elliot's and and/or Royall's sites (Murphy, 1999). However, the shell jewelry and ornamental objects we examined were made from only two species: (1) predominantly, the queen conch (Strombus gigas); and (2) to a lesser extent, the thorny oyster (Spondylus americanus).
Many shells are composed of aragonite when initially formed by the living shellfish. However, aragonite is not a stable mineral and, especially in the marine environment, the outer part will rapidly (in a matter of years) convert to calcite (figure 11). Thus, depending on what part of the shell is used for jewelry, the piece could contain aragonite and/or calcite. Most of the specimens in this study are aragonite.

The skill with which Saladoid craftsmen designed and manufactured ornamental shell objects may be gauged from the disc-shaped beads shown in figures 12 and 13, and from the pendants in figure 14. Zoomorphic (e.g., animal heads; see the bird-shaped pendant in figure 14) and anthropomorphic (e.g., human faces; see figure 3) themes are common and also skillfully produced in shell throughout the region inhabited by the Saladoid culture. Figure 15 illustrates zemis carved from shell material.

Figure 12. These white beads and a blank from the queen conch (Strombus gigas) were found at the Royall's site. All are composed of aragonite. The blank is about $34 \mathrm{~mm}$ in its longest dimension, and the smallest bead is about $3 \mathrm{~mm}$ in diameter.

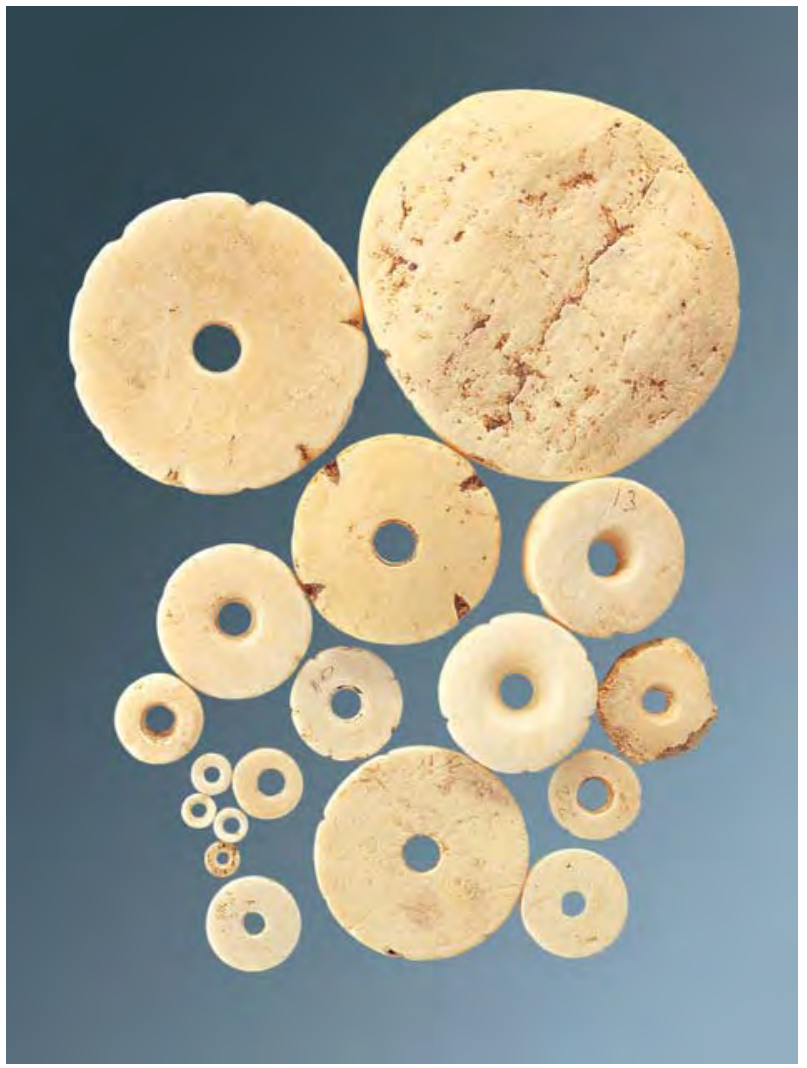




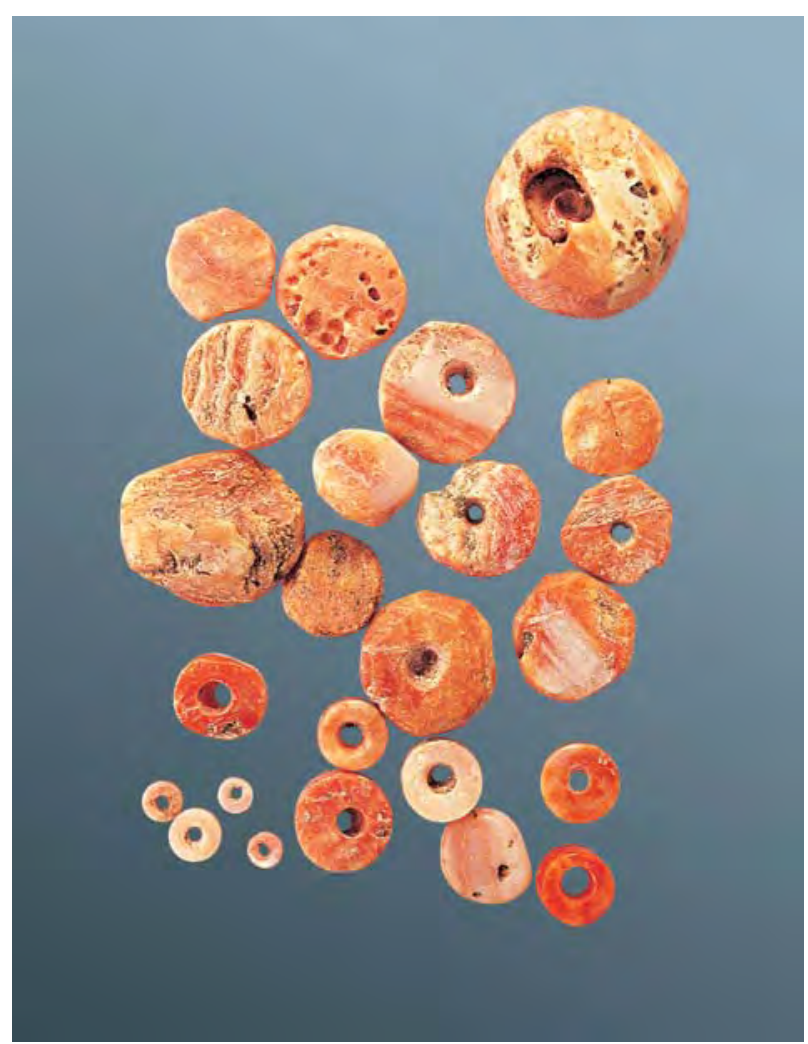

Figure 13. Red beads and blanks from the Royall's site represent all stages of bead production. Composed of calcite, they originate from the outer part of the thorny oyster shell. The largest blank is about $15 \mathrm{~mm}$ in its longest dimension, and the smallest bead has an external diameter of about $2.5 \mathrm{~mm}$.

Rocks. The coarse-grained, unaltered diorites vary from light to dark, as determined by the relative amounts of white and black minerals (see figures 1 and 16). Thin-section examination revealed that the diorite is composed of variable amounts of plagioclase and amphibole, with minor quartz.

Most of the limestones are light colored, but some have dark streaks or zones of organic matter. Three specimens from Royall's are composed of calcite and have the distinctive wavy textures of travertine (see, e.g., figure 17); we have classified them as limestones.

The tuff specimens showed the greatest variation in color appearance, texture, and mineral composition of the three rock types studied (again, see figures 1 and 7). They were also the most problematic to classify. In general, the tuff samples are light to medium green, have an altered fine-grained matrix, and have a low specific gravity; these characteristics reflect tuff's origin as consolidated volcanic ash.

\section{DISCUSSION}

Sources of the Lapidary Materials. Even though Antigua is a small island, most of the gem materials and rocks listed in table 1 are known to occur there. Barite, carnelian, chalcedony, chert, jasper, and quartz (both transparent and translucent) were mentioned in the geologic literature of the early to mid-19th century (Anonymous, 1818; Nugent, 1818, 1821; Hovey, 1839). Martin-Kaye (1959) described a barite quarry from which this mineral was mined between 1942 and 1945; he also mentions two small occurrences of malachite that are found as accumulations (as pockets or flakes) or stains within tuffs. Shell is abundant in the waters and reefs surrounding Antigua, as well as in certain units of the Antigua Formation. Limestone and tuff are common constituents of the Antigua Formation and Basal Volcanic Suite, respectively. The diorite may have come from an outcrop on the south coast of Antigua that was documented by Multer et al. (1986).

Calcite has not been reported from Antigua as transparent or translucent crystals or masses, although it may be present in solution cavities in limestones of the Antigua Formation. The same observation applies to travertine. Indeed, at the American Museum of Natural History in New York, there are etched "dog tooth" calcite crystals up to $4 \mathrm{~cm}$ in length, with clear portions inside, that are reportedly from St. John's, Antigua (G. E. Harlow, pers. comm., 1999). Thus, we believe that the calcite found at both the Elliot's and Royall's sites is probably of local origin.

There are no geologic reports or known occurrences of amethyst, nephrite, serpentine, or turquoise on Antigua. Given the geology of the island, we do not expect them to be presentalthough we recognize that since carnelian, chalcedony, and quartz exist on the island, the occurrence of amethyst is a possibility, especially in the basalts. We propose that amethyst, nephrite, serpentine, and turquoise are of nonlocal origin. Noteworthy is the fact that there are only 11 such nonlocal specimens (about $2 \%$ of the total), and these have been found only as finished objects.

Other Saladoid Lapidary Sites in the Eastern Caribbean. Comparison of our data to those obtained from three well-documented Saladoid lapidary sites of comparable age on three islands in the eastern Caribbean (figure 2) is instructive. The three sites are: Vieques Island, Puerto Rico /Chanlatte 


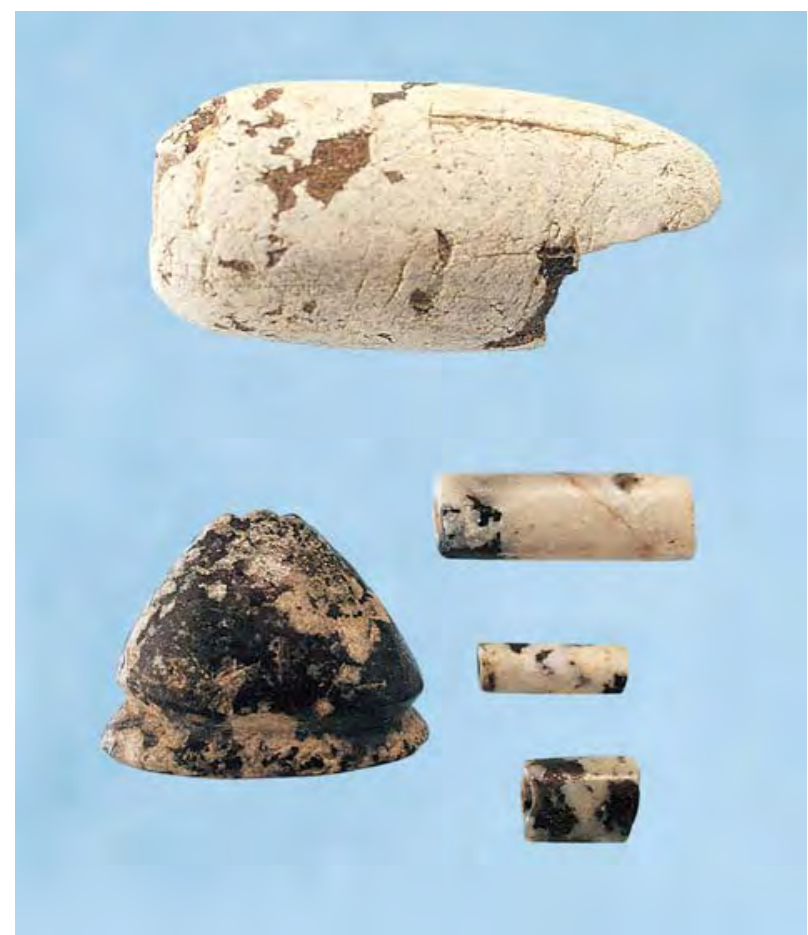

Figure 16. The color of diorite varies depending on the proportion of light and dark minerals (predominantly plagioclase and amphibole, respectively) that are present, as shown by these four beads and a zemi from the Elliot's site. The largest bead measures about $4.4 \mathrm{~cm}$, and is broken.

some have dark orangy red rinds surrounding white opaque chalcedony, some have a banded texture with the bands ranging in color from orangy red to white, and some are translucent with only a slight reddish color), which suggests the same geologic source. As carnelian is reportedly nonlocal to Montserrat, it is possible that the supply of this material came from Antigua, which suggests trading between these two islands.

Sources of the Nonlocal Materials. The four nonlocal worked minerals (amethyst, nephrite, serpentine, and turquoise) from Antigua are also found at most of the other eastern Caribbean sites. A challenge for archeologists has been to determine the original source of these minerals. Most favor South America, because of the generally accepted migration path of the Saladoid people (see above). Possible South American sources are hypothesized by Cody $(1990,1991$ a) for amethyst (Brazil and Guyana), nephrite (Brazil, Guyana, and Venezuela), serpentine (Venezuela), and turquoise (Brazil and Chile), based solely on their known geologic occurrences. Turquoise from the southwestern U.S. seems unlikely, because significant mining did not start there until about the 5th century AD (Ball, 1941). Several authors (e.g., Rodríguez, 1991) suggest southwestern Puerto Rico as a source of serpentine. Nevertheless, with respect to South American sources for the nonlocal gem materials found in the Caribbean Islands, Watters (1997a, p. 7) pointed out that "empirical evidence of such sources is largely lacking."

\section{CONCLUSION}

A flourishing lapidary industry, attributed to people of the Saladoid culture, existed on Antigua during the period 250-500 AD. From excavations at the Elliot's and Royall's archeological sites, 13 gem materials (including shell) and three rock types used for gem and ornamental purposes have been identified. Most of the jewelry artifacts recovered (mainly beads) were made of shell. Calcite, carnelian, quartz, diorite, and limestone were also important lapidary materials. Eleven of the 642 specimens studied are composed of minerals (amethyst, nephrite, serpentine, and turquoise) that do not

Figure 17. These bead blanks from the Royall's site are made of limestone, probably travertine. The larger one measures about $3 \mathrm{~cm}$.

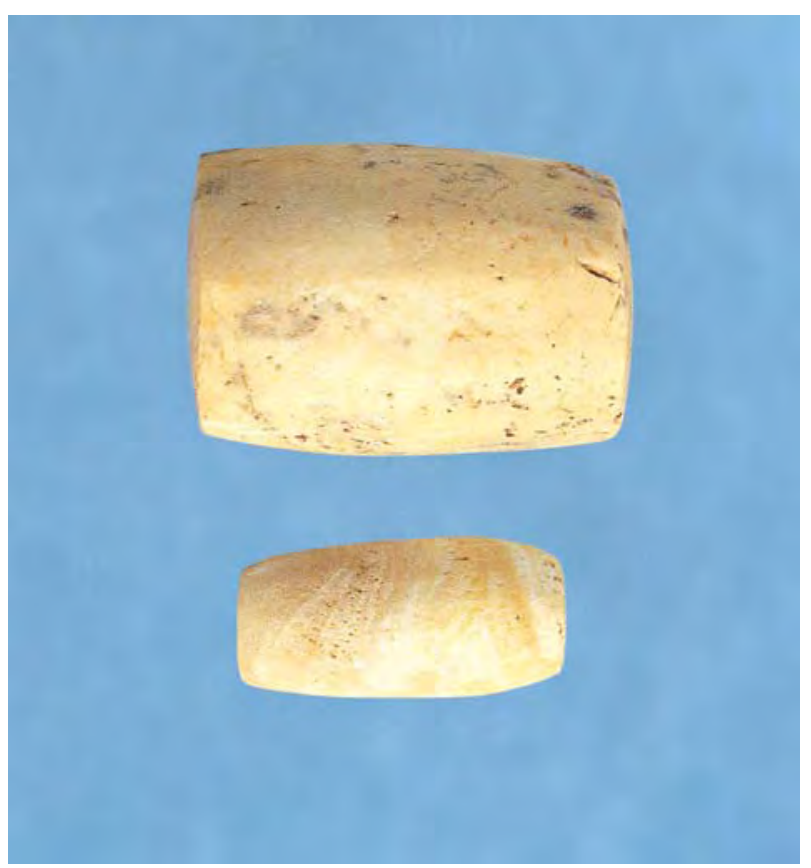


occur on Antigua. These were found only as finished objects, and apparently arrived on Antigua as a result of trade. We can only speculate as to the geographic origins of these nonlocal samples.

The lapidary industry in Antigua appears to have similarities with that at nearby Montserrat, specifically in that carnelian was important among the stone objects at both sites. This article demonstrates how the gemological characterization of ancient gem materials can help archaeologists locate the source of the rough materials used in ancient jewelry and suggest early trade patterns.
Acknowledgments: Dr. Murphy thanks Dr. D. R. Watters of the Carnegie Museum of Natural History in Pittsburgh for supplying the authors with rare literature references, and John Fuller of Antigua for field assistance. The authors also thank the following (all at the University of Calgary): Dr. G. Newlands, who took all specimen photos not acknowledged to others; M. Glatiotis, for assisting with chemical analyses using the scanning electron microscope and for X-ray diffraction analyses; J. Resultay, for preparing thin sections; and Professors L. V. Hills, J. W. Nicholls, and R. J. Spencer, for helpful discussions. I. I. Koivula at GIA in Carlsbad kindly performed the Raman analyses.

\section{REFERENCES}

Allaire L. (1997) The Lesser Antilles before Columbus. In S. M. Wilson, Ed., The Indigenous People of the Caribbean, University Press of Florida, Gainesville, FL, pp. 20-28.

Anonymous (1818) Petrified wood from Antigua. American Journal of Science, Vol. 1, pp. 56-57.

Ball S.H. (1941) The mining of gems and ornamental stones by American Indians. Smithsonian Institution, Bureau of American Ethnology Bulletin No. 128, Anthropological Papers, No. 13, pp. 1-77.

Chanlatte Baik L.A. (1983) Catálogo Arqueología de Vieques. Museo de Antropología, Historia y Arte, Universidad de Puerto Rico, Recinto de Río Piedras, 90 pp.

Cody A.K. (1990) Prehistoric patterns of exchange in the Lesser Antilles: Materials, models, and preliminary observations. M.A. thesis, San Diego State University, 422 pp. [University Microfilms, No. 1344090]

Cody A. (1991a) Distribution of exotic stone artifacts through the Lesser Antilles: Their implications for prehistoric interaction and exchange. In A. Cummins and P. King, Eds., Proceedings of the Fourteenth Congress of the International Association for Caribbean Archaeology, Barbados, 1991, pp. 204-226.

Cody A.K. (1991b) From the site of Pearls, Grenada: Exotic lithics and radiocarbon dates. In E.N. Ayubi and J.B. Haviser, Eds., Proceedings of the Thirteenth Congress of the International Association for Caribbean Archaeology, Curaçao, 1990, Reports of the Archaeological-Anthropological Institute of the Netherlands Antilles, No. 9, Willemstad, Curaçao, pp. 589-604.

Crock J.G., Bartone R.N. (1998) Archaeology of Trants, Montserrat, Part 4: Flaked stone and stone bead industries. Annals of Carnegie Museum, Vol. 67, No. 3, pp. 197-224.

Hovey S. (1839) Geology of Antigua. American Journal of Science, Vol. 35, pp. 75-85.

Hurlbut C.S., Kammerling R.C. (1991) Gemology, 2nd ed. John Wiley, New York.

Jackson J.A. (1997) Glossary of Geology, 4th ed. American Geological Institute, Alexandria, VA.

Martin-Kaye P.H.A. (1959) Reports on the Geology of the Leeward and British Virgin Islands. Voice Publishing Co., St. Lucia, 117 pp.

Martin-Kaye P.H.A. (1969) A summary of the geology of the Lesser Antilles. Overseas Geology and Mineral Resources, Vol. 10, No. 2, pp. 172-206.

Multer H.G., Weiss M.P., Nicholson D.V. (1986) Antigua. Reefs,
Rocks et Highroads of History, Contribution No. 1, Leeward Islands Science Associates, St. John's, Antigua.

Murphy A.R. (1999) The prehistory of Antigua, Ceramic Age: Subsistence, settlement, culture and adaptation within an insular environment. Ph.D. thesis, Department of Archeology, University of Calgary, Calgary, Alberta, Canada, 320 pp.

Nicholson D.V. (1991) The Story of English Harbour. Historical and Archeological Society of Antigua, St. John's, Antigua.

Nicholson D.V. (1993) The Archaeology of Antigua and Barbuda. Museum of Antigua and Barbuda, St. John's, Antigua.

Nugent N. (1818) Notices of geology in the West-Indies. American Journal of Science, Vol. 1, pp. 140-142.

Nugent N. (1821) A sketch of the geology of the island of Antigua. Transactions of the Geological Society (London), Vol. 5, pp. 459-475.

Rodríguez M. (1991) Early trade networks in the Caribbean. In A. Cummins and P. King, Eds., Proceedings of the Fourteenth Congress of the International Association for Caribbean Archaeology, Barbados, 1991, pp. 306-314.

Rouse I. (1976) The Saladoid sequence on Antigua and its aftermath. In R. P. Bullen, Ed., Proceedings of the Sixth International Congress for the Study of Pre-Columbian Cultures of the Lesser Antilles, Gainesville, FL, pp. 35-41.

Rouse I. (1992) The Tainos: Rise and Decline of the People Who Greeted Columbus. Yale University Press, New Haven, CT.

Watters D.R. (1997a) Stone beads in the prehistoric Caribbean. Bead Study Trust Newsletter, No. 29, Spring, pp. 7-8.

Watters D.R. (1997b) Maritime trade in the prehistoric eastern Caribbean. In S. M. Wilson, Ed., The Indigenous People of the Caribbean, University Press of Florida, Gainesville, FL, pp. 88-99.

Watters D.R., Scaglion R. (1994) Beads and pendants from Trants, Montserrat: Implications for the prehistoric lapidary industry of the Caribbean. Annals of Carnegie Museum, Vol. 63, No. 3, pp. 215-237.

Weiss M.P. (1994) Oligocene limestones of Antigua, West Indies: Neptune succeeds Vulcan. Caribbean Journal of Science, Vol. 30, No. 1-2, pp. 1-29.

Wilson S.M., Ed. (1997a) The Indigenous People of the Caribbean. University Press of Florida, Gainesville, FL.

Wilson S.M. (1997b) Introduction to the study of the indigenous people of the Caribbean. In S. M. Wilson, Ed., The Indigenous People of the Caribbean, University Press of Florida, Gainesville, FL, pp. 1-8. 